\title{
Hipnoterapy Toward Improving The Confidence Of Students
}

\author{
Sri Wahyuni Rifai ${ }^{1}$, Asnidar ${ }^{2}$, Edison Siringoringo ${ }^{3}$ \\ S1 Nursing Study Program, Stikes Panrita Husada Bulukumba, Indonesia ${ }^{1}$ \\ Departemen Mental Health Nursing , Stikes Panrita Husada Bulukumba ,Indonesia ${ }^{2}$ \\ Departemen Community and Family Nursing , Stikes Panrita Husada Bulukumba, Indonesia ${ }^{3}$
}

Corresponding Autor : asnidarnidar16@yahoo.com

\begin{abstract}
The problem of confidence is one of the global phenomena that everyone has. This event does not only occur in Indonesia but also in other countries. From the results of preliminary studies conducted by researchers, more respondents experienced low self-esteem than moderate and high self-esteem. The purpose of this study was to determine the effect of hypnotherapy on increasing the confidence of students in the fourth semester of the S1 undergraduate study program in the learning process at Stikes Panrita Husada Bulukumba. This research method uses a Pre-experimental design with the One group Pretest-Posttest Design approach. Sampling was done by a systematic random sampling technique. The population in this study was 46 people. The sample in this study were 19 people. Data analysis uses the Marginal Homogeneity alt Wilcoxon test. The results of SPSS analysis using the statistical test Marginal Homogeneity alt Wilcoxon obtained the value $(p=0.001)$ so that it can be concluded that there is a significant influence between hypnotherapy on increasing the confidence of fourth-semester students of a nursing S1 study program in the learning process at Stikes Panrita Husada Bulukumba.
\end{abstract}

Keywords: Hypnotherapy, Confidence

\section{INTRODUCTION}

Confidence is one of the psychological conditions of a person that affects physical and mental activity in the learning process. Confidence generally arises when someone will do or engage in a particular activity where his mind is directed to achieve the desired results (Aunurrahman, 2010 in Sheenah Hankin, 2014). The problem of confidence is one of the global phenomena that everyone has. This incident not only occurred in Indonesia, but also experienced in other countries. One example is the result of research Gill (2015) said that nearly 23\% of junior high school-age teens in California experience low self-confidence. In addition, research conducted by Simbolon in 2013 in SMP NEGERI 29 Bandung, found 19\% of students who also experienced low self-confidence.

Drajat (2014 in Sheenah Hankin 2014) said that one of the things that greatly influences social interaction is the self-confidence of the individual himself, so the high 
level of confidence possessed by adolescents will make him feel very confident when interacting with others and can show skills himself speaking in public and while in class.

Students with high confidence will have advantages in several ways, as conveyed by Wibowo (2014) in a journal that students with high confidence are more independent, do not depend on others, are able to assume the responsibilities given, respect themselves, are not easy to practice, ready to accept challenges and new targets, have stable emotions. Although many say that self-confidence is important and must be owned by everyone, in fact there are still many students with low levels of confidence.

Many experts have conducted research on self-confidence, and one of them is Cheng and Furham (2012) whose research shows that self-confidence is an important thing that can support human success and happiness. In his research also proved that selfconfidence is one part of aspects of personality that has an important role in the lives of individuals.

Based on Miftahurrohmah's research (2017) with the title "effectiveness of the use of hypnotherapy personality part retrieval techniques to overcome low self-esteem of students in class VIII smpn 3 Kediri" using the Wilcoxon test obtained the value of $\mathrm{P}=$ $0.002<0.005$ which means there is a positive change that is an increase in confidence with the use of low self-confidence class VIII grade 3 students. hynotherapy, retrieval personality part technique. In line with the results of Siti Imro'atun's research (2017) with the title "effectiveness of group counseling services to increase the confidence of junior high school students" using the Wilcoxon Signed Ranks Test shows that there are significant differences after the administration of action so it can be said that $\mathrm{HO}$ is rejected. This significant difference is seen in the different levels of confidence held by the two groups. Experimental group have a high average level of confidence while the control group has a moderate average of confidence.

The data obtained at the Panrita Husada College of Health Sciences Bulukumba Department of Nursing S1 obtained four registered semester students who participated in the learning process as many as 46 students. Through a preliminary study on the Panikes Strada Husada Bulukumba Campus after an interview with fourth semester students of Nursing S1 said that the question and answer process during learning in class made them feel doubtful, ashamed and hesitant about their own abilities. Feelings that appear suddenly and haunt their feelings due to not wanting to be laughed at by friends. 
The purpose of this study was to determine whether there is an influence of hypnotherapy on increasing the confidence of fourth semester students of undergraduate nursing programs in the learning process at Stikes Panrita Husada Bulukumba.

\section{MATERIAL AND METHODS}

This research design uses Pre-experimental research design with One Group Pretest-Posttest Design research design in this design there is a pretest, before the treatment is carried out, so the treatment results can be known more accurately, because it can compare with the situation before being treated (Sugiyono, 2012).

Population is a generalization area that consists of objects / subjects that have certain quantities and characteristics determined by researchers to be studied and then drawn conclusions (Sugiyono, 2012). The population in this study were all students who were in the fourth semester learning process programmed by S1 Nursing Panrita Husada Bulukumba undergraduate nursing with a total of 46 students.

Sampling in this study uses a systematic random sampling method that is sampling randomly (random) which is done by lottery, ordinal, or random number tables or by computer (Sugiyono, 2012). The number of samples in this study were 19 respondents. The research instrument is a tool used to measure observed natural and social phenomena (Sugiyono, 2012). The instrument in this study was a questionnaire (questionnaire). Questionnaires are data collection conducted by giving a set of questions or written statements to respondents to be answered (Sujarweni, 2014).

Data were analyzed based on measuring scale and research objectives using computerized program software. Data were analyzed by: (1). Univariate Analysis is an analysis conducted to analyze variables. (2). Bivariate Analysis, Bivariate Test is an analysis carried out by more than two variables. The statistical test used was marginal homogeneity alt Wilcoxon test. This test aims to see the presence or absence of a significant significant effect between the observed frequency distribution with the expected degree of significance 0.05 . If $\mathrm{P}$-Value $<0.05$ means there is a significant influence (Ho is rejected) while P-Value $>0.05$ means there is no significant effect (Ho is accepted). 
RESULTS

Table 1. Frequency Distribution of Respondents by Student Gender And Age

\begin{tabular}{lcc}
\hline Gender & Frequency (f) & Percentage (\%) \\
\hline Male & 2 & 10.5 \\
Girl & 17 & 89.5 \\
Age & & \\
19 & 9 & 47.4 \\
20 & 9 & 47.4 \\
21 & 1 & 5.3 \\
\hline Amount & 19 & $\mathbf{1 0 0 . 0}$ \\
\hline
\end{tabular}

Based on table 1 it can be seen that the lowest sex of respondents is male as much as 2 respondents or (10.5\%) and the most respondents are women as many as 17 respondents or (89.5\%). Based on table it can be seen that the lowest age of respondents is 21 years by 1 respondent or (5.3\%) and the age of most respondents is 19 years and 20 years, each of which amounted to 9 respondents or (47.4\%).

Table 2. Frequency Distribution of Respondents Based on Confidence Level

\begin{tabular}{|c|c|c|}
\hline Pre Test Confidence & $\mathrm{n}$ & Precentage (\%) \\
\hline Low & 11 & 57.9 \\
\hline Medium & 8 & 42.1 \\
\hline High & 0 & 0.0 \\
\hline Amount & 19 & 100.0 \\
\hline
\end{tabular}

Based on table 2 it is obtained that the level of confidence of fourth semester students of undergraduate nursing study programs before being given hypnotherapy intervention the highest value is the low confidence category of 11 respondents (57.9\%) while the lowest value is the medium confidence category of 8 respondents (42.1\%) and confidence in the high category by $0 \%$.

Table 3. Frequency Distribution of Respondents Based on Confidence Level

\begin{tabular}{lccc}
\hline & Post Test Confidence & Frequency (f) & Precentage (\%) \\
\hline Low & 5 & 26.3 \\
Medium & 3 & 15.8 \\
High & 11 & 57.9 \\
\hline Amount & 19 & 100.0 \\
\hline
\end{tabular}

Based on table 3 it is obtained that the level of confidence of fourth semester students of Bachelor of Nursing study programs after being given hypnotherapy intervention the highest value is the high category of 11 respondents (57.9\%) while the lowest value is the medium category of 3 respondents $(15.8 \%)$ and the value of confidence in the low category was 5 respondents (26.3\%). 
Table 4. The Influence of Hypnotherapy Distribution on Increasing Confidence

\begin{tabular}{lccccc}
\hline & \multicolumn{2}{c}{ Pretest Hypnoterapi } & \multicolumn{2}{c}{ Posttest Hypnoterapi } & P Value \\
\hline & $\mathbf{n}$ & Percentage (\%) & $\mathbf{n}$ & Percentage (\%) & \\
\hline High & 0 & 0,0 & 11 & 57,9 & 0,001 \\
Medium & 8 & 42,1 & 3 & 15,8 & \\
\multirow{2}{*}{ Low } & 11 & 57,9 & 5 & 26,3 & \\
\hline Amount & 19 & $\mathbf{1 0 0}$ & $\mathbf{1 9}$ & $\mathbf{1 0 0}$ & \\
\hline
\end{tabular}

Based on table 4. shows that after hypnotherapy there was an increase in the confidence of respondents with a high category that is from 0 respondents $(0.0 \%)$ to 11 respondents (57.9\%), as well as the moderate category of 8 respondents $(42.1 \%)$ became 3 respondents (15.8\%) and the low category from respondents (57.9\%) to 5 respondents (26.3\%). Statistical test results obtained p value $=0.001<0.005$, this shows there is an influence of hypnotherapy on increasing the confidence of fourth semester students of nursing study programs in the learning process at Panrita Husada Bulukumba.

\section{DISCUSSION}

This study shows that there is an influence of hypnotherapy on increasing the confidence of fourth semester students of S1 Nursing Study Program in the learning process at Panrita Husada Bulukumba Stikes.

Based on statistical results performed using the Wilcoxon marginal homogeneity alt test, the $\mathrm{p}$ value $=0.001$ is smaller than the $\alpha=0.005$ value. Then Ho is rejected and Ha is accepted. This proves that hypnotherapy affects the increase in self-confidence of the fourth semester students of S1 Nursing Study Program in the learning process at Panukita Husada Stikes in Bulukumba. This is in line with research conducted by Miftahurrohmah (2017) with the title "the effectiveness of using hypnotherapy personality part retrieval techniques to overcome the low self-confidence of students in grade VIII junior high school 3 in Kediri" using the Wilcoxon test obtained a value of $\mathrm{P}=$ $0.002<0.005$ which means there is a positive change that is increased self-confidence with the use of retrieval personality part technique hynotherapy. This is also in line with research conducted by Siti Imro'atun (2017) with the title "effectiveness of group counseling services to increase the confidence of junior high school students" using the Wilcoxon Signed Ranks Test shows that there are significant differences after the administration of action so that it can it is said that HO is rejected. This significant difference is seen in the different levels of confidence held by the two groups. The 
experimental group had a high average level of confidence while the control group had a moderate average level of confidence. Also in line with Budiman's research (2016) with the title "effectiveness of hypnotherapy anchor techniques on changes in adolescent smoking behavior" study of clients in Palembang's Center of Hypnotherapy maulana clinic "intended changes are leading to better behavior ie, out of 15 people treated with using hypnotherapy with anchor technique 11 people quit smoking while 2 people can reduce the intensity and frequency of smoking by 78\% while for 2 more people are only able to reduce the intensity of smoking $56.3 \%$. By using paired t test obtained p value of (0.00) smaller than alpa (0.05) which means that there is an influence of the hypnotherapy program with the method anchor to teenage smoking behavior. The average pre-test adolescent smoking behavior value is 70.41 with a standard deviation of 10.58 .

The researcher believes that the lack of activeness in the learning process in the classroom is related to the lack of self-confidence because the weaknesses that exist in a person are often the cause of sudden emergence or loss of self-confidence, parenting patterns that often forbid parents, trauma from past failures and trauma is humiliated or humiliated in public, they only tend to be quiet and attentive rather than directly involved in the learning process such as discussion among peers and lecturers because of the shame and doubt that haunts their feelings there is a lack of self-confidence.

The researcher also believes that the increase in self-confidence occurs due to hypnotherapy activities which indeed in this situation require a way or a way to increase their self-confidence in the learning process because of which they are often haunted by doubt, shame being laughed at and afraid to express an opinion, in this case also supported by information provided by the facilitator to respondents related to confidence such as explaining what confidence is and making interventions in the form of hypnotherapy and these are things that become a way of increasing confidence and less confidence can be overcome. While the events that occur where there are still students with low self-confidence category after hypnotherapy intervention is a result of a weak subconscious or an individual who cannot control his subconscious well, a weak subconscious greatly influences the effectiveness of hypnotherapy interventions in which individuals can not strongly absorb the suggestions given. 


\section{CONCLUSIONS}

Based on the results of the study above, it was concluded that there was a significant influence between hypnotherapy on increasing the confidence of fourth semester students of nursing study program in the learning process at STIKES Panrita Husada Bulukumba in 2018. The results of this study hopefully could be used as insight material and increase knowledge about the effects of hypnotherapy towards increasing self-confidence of fourth semester students of S1 nursing study program in the learning process at STIKES Panrita Husada Bulukumba. As a reference data for the Stikes Panrita Husada Bulukumba campus so that it can assist other researchers in recording overall confidence and for students to be more confident again in the process learning and more actively training yourself in asking questions or expressing opinions without being accompanied by doubt, shame, and fear of being laughed at.

\section{REFERENCES}

Hankin Sheenah, Ph.D (2014). Strategi untuk meningkatkan rasa percaya diri. Jakarta: Gramedia Pustaka Utama.

Miftahurrohmah (2017). Efektivitas penggunaan hypnoterapi teknik personality part retrieval untuk mengatasi percaya diri rendah tahun ajaran 2016/2017. Universitas Nusantara PGRI Kediri

Imro'atun Siti (2017). Keefektifan layanan konseling kelompok untuk meningkatkan kepercayaan diri siswa sekolah menengah pertama. JKBK (Jurnal Kajian Bimbingan dan Konseling).

Budiman (2016). Efektivitas hipnoterapi teknik anchor terhadap perubahan perilaku merokok remaja "studi pada klien diklinik maulana center of hypnoterapi Palembang". Psikis - Jurnal Psikologi Islami

Sujarweni, W. (2014). Metodologi Penelitian Keperawatan. Yogyakarta: Gava Media.

Sugiyono. (2012). Metode Penelitian Kuantitatif Kualitatif dan R\&D. Bandung: Alfabeta.

Al-Uqshari Yusuf (2014). Percaya diri pasti. Jakarta: Gema insani.

Drs. Hendra Surya, dkk (2013). Percaya diri itu penting. Jakarta: Gramedia Pustaka utama.

Setyawan Angga (2014). Percaya diri bermakna luas. Jakarta: Mizan Publika.

Iswidharmanjaya Derry, dkk (2014). Suatu hari menjadi lebih percaya diri. Jakarta: Gramedia Utama 
Said bin fahmi (2015). Hubungan rasa percaya diri dan motivasi berprestasi dengan mutu hasil belajar mahasiswa politeknik kesehatan banjarmasin program studi kesehatan gigi Banjarmasin. Universitas Banjarmasin

Asiyah Nur (2014). Pola asuh demokratis, kepercayaan diri dan kemandirian mahasiswa baru. Jurnal Psikologi Indonesia

Aziz M. Abdul (2016). Pengaruh antara kepercayaan diri terhadap penyesuaian diri pada siswa remaja kelas $x$ di sekolah menengah akhir muhammadiyah 5 karanggeneng. PSIKOSAINS

Rahayuningdyah Endah (2015). Upaya meningkatkan kepercayaan diri melalui layanan konseling kelompok pada siswa kelas viii d di smp negeri 3 ngrambe. Jurnal Kopasta

Syahrunanca Raefri \& Astorini W Dyah (2015). Hubungan antara kepercayaan diri dengan kreativitas kelompok belajar "sekolah kami" di bekasi. Universitas Muhammadiyah Purwokerto

Ristantia \& Rofiqah Tamama (2015). Keefektifan layanan bimbingan kelompok ditinjau dari kepercayaan diri siswa kelas xi ips di man batam. Jurnal Kopasta

Kusrini Woro \& Prihartanti Nanik (2016). Hubungan dukungan sosial dan kepercayaan diri dengan prestasi bahasa inggris siswa kelas viii smp negeri 6 boyolali. Universitas Muhammadiyah Surakarta

Hidayat Ahmad \& Kurniawan Chandra (2016). Pengaruh konsep diri dan kepercayaan diri terhadap perilaku konsumtif pembelian gadget pada mahasiswa fakultas hukum non reguler universitas islam riau. Universitas Islam Riau

Jarmitia Sri, dkk (2014). Hubungan antara dukungan sosial dengan kepercayaan diri pada penyandang disabilitas fisik di slb kota banda aceh. Jurnal Psiko Islamedia

Khasanah Lailatul \& Astuti Tri Retna (2016). Efektivitas akupresur dan hipnoterapi dalam mengatasi dismenore pada remaja putri di smk muhammadiyah salaman. Jurnal Kopasta

Syam Asrullah (2017). Pengaruh kepercayaan diri (self confidence) berbasis kaderisasi imm terhadap prestasi belajar mahasiswa (studi kasus di program studi pendidikan biologi fakultas keguruan dan ilmu pendidikan universitas muhammadiyah parepare). Universitas Muhammadiyah Pare-pare

Rupang indra, dkk (2017). Hubungan tingkat kepercayaan diri dengan obesitas pada siswa sma rex mundi manado. Jurnal e-Biomedik

Komara Bangkit Indra (2017). Hubungan antara kepercayaan diri dengan prestasi belajar dan perencanaan karir siswa. Universitas Ahmad Dahlan

Dwiduonova Febian, dkk (2015). Hubungan antara citra tubuh dengan kepercayaan diri pada remaja pelajar puteri di kota denpasar. Jurnal Psikologi Udayana 
Marjanti Sri (2015). Upaya meningkatkan rasa percaya diri melalui konseling kelompok bagi siswa x ips 6 sma 2 bae kudus tahun pelajaran 2014/2015. Jurnal Konseling GUSJIGANG

Agusriani Ade (2015). Peningkatan kemampuan motorik kasar dan kepercayaan diri melalui bermain gerak. Jurnal Pendidikan Usia Dini

Rachmawati Rani, dkk (2016). Metode keperawatan komplementer hipnoterapi untuk menurunkan efek stress pasca trauma tingkat sedang pada fase rehabilitasi sistem penanggulangan kegawatdaruratan terpadu (spgdt). Jurnal Keperawatan

Irianto Ady, dkk (2014). Pengaruh hipnoterapi terhadap penurunan tingkat kecemasan pada pasien yang menjalani kemoterapi di rs telogorejo semarang. Jurnal Ilmu Keperawatan dan Kebidanan (JIKK)

Agustini Ratih Ayu I Gusti (2014). Pengaruh hypnotherapy terhadap intensitas nyeri pada ibu bersalin normal di rsud wangaya kota denpasar. Jurnal Ilmu Keperawatan dan Kebidanan (JIKK)

Widyaningtyas Diva \& Farid M (2014). Pengaruh experiential learning terhadap kepercayaan diri dan kerjasama tim remaja. Persona, Jurnal Psikologi Indonesia

Wahyuni Sri (2017). Hubungan antara kepercayaan diri dengan kecemasan berbicara di depan umum pada mahasiswa psikologi. Ejurnal Psikologi

Affandi Maulana Ibnu (2015). Pengaruh terapi relaksasi napas dalam dan hypnosis lima jari terhadap tingkat stress mahasiswa program studi ilmu keperawatan universitas 'aisyiyah Yogyakarta. Universitas 'Aisyiyah Yogyakarta

Putra P Yovan (2016). Rahasia dibalik hipnosis Erickson dan metode pengembangan pikiran. Jakarta: Katalog Dalam Terbitan (KDT)

Hidayat, A.Aziz, (2014). Metode penelitian keperawatan dan teknik analisis data. Jakarta selatan: salemba medika.

Hunter C. Roy (2015) Seni hipnosis penguasaan teknik-teknik dasar. Edisi III. Permata puri media . Jakarta

KNEPK, (2012). Etika penelitian

Nursalam, (2016). Metodologi penelitian ilmu keperawatan pendekatan praktis, ed 4. Jakarta: Salemba medika.

Syamsuddin et.al., (2015). Pedoman Praktis Metode Penelitian Internal. Ponorogo: CV. Wade Group.

Ns. Triyadi Aang, CHt, CI (2018). Hipnonursing (Hyonoterapi For Nurse \& Midwife).

Kuningan: CV. Mentari sukses 